\title{
Memoria y olvido de una ministra anarquista
}

\author{
Ángel Herrerín López
}

\begin{abstract}
RESUMEN ABSTRACT
Este artículo analiza como la imagen histórica de Federica Montseny ha ido variando con el paso del tiempo. Para dicho análisis se utiliza una doble óptica: por un lado, la visión que nos aportan, a través de sus memorias, sus compañeros libertarios; $y$ por otro, como es tratada, esa imagen, por la empresa publicista.

PALABRAS CLAVE Anarquismo, Memoria Histórica, Federica Montseny, CNT, Exilio.

This article analyses Federica Montseny's historical image which has changed throughout time. A double point of view is used to do it: On one, hand the vision that her anarchist colleagues provide thorugh their memories, and on the other hand, we can see the way that her image has been treated by the standard press.

KEY WORDS

Anarchims, Historical Memory, Federica Montseny, CNT, Exile.
\end{abstract}

Federica Montseny nació el 12 de febrero de 1905 en Madrid, fue hija de Juan Montseny y de Teresa Mañé, más conocidos como Federico urales y Soledad Gustavo, matrimonio que fue procesado en numerosas ocasiones por sus ideas racionalistas y libertarias. Promoverían campañas contra el gobierno para la revisión de los procesos de Montjuich. Por estas actuaciones, Juan Montseny será encerrado en prisión durante un año y enviado, después al destierro, a Inglaterra. Regresó a España con el nombre de Federico Urales, instalándose en madrid, -momento en el que nacerá Federica-, ciudad que abandonaría en 1911 para ir a Barcelona, entre otras cosas, por una sentencia de un tribunal que le condenaba a un 
destierro de 20 años por unas acusaciones que hizo en la prensa sobre la "Compañia Madrileña de Urbanización", promotora de la Ciudad Lineal.

Será detenido tras el atentado de Morral contra los reyes. Defenderá a Francisco Ferrer, fundador de la Escuela Moderna, acusado de ser el "cerebro» de la «Semana Trágica» 1.

Además de estas actividades políticas, la familia Montseny tendrá una vertiente intelectual que será muy importante en la vida de Federica; serán los fundadores de "la Revista Blanca». Su madre era maestra:

“...Mi madre empezó siendo maestra. Entró en el librepensamiento y fue la primer maestra laica, o una de las primeras, que hubo en España, en una campaña de laicización anterior a la de Ferrer i Guardia. Fue una de las primeras maestras en una de las escuelas fundadas por Gabarró, un librepensador que fundó muchas escuelas, sobre todo en Cataluña..." ${ }^{2}$.

Por todo ello, la educación que recibiría Federica Montseny fue diferente a la generalidad:

“...Hasta los catorce o quince años puede decirse que fue mi madre quien me educó. Después aprendi idiomas en la Academia Cots y en la Escuela Berlitz y me inscribí en la Facultad de Filosofía y Letras de la Universidad de Barcelona, aunque como oyente, es decir, sin pasar exámenes" 3 .

En los años 1916-1917, con doce años, acompañaba a su padre a mítines, manifestaciones y cafés donde se reunían los intelectuales de izquierda y periodistas; así, sería su padre el que la introdujera en círculos anarquistas y con el que haría la reaparición de "la Revista Blanca». En el ambiente de 1919, Federica fue formando su conciencia revolucionaria:

“... tomando apasionadamente posición a favor de las víctimas y en oposición a las fuerzas reaccionarias y capitalistas (...) y de las bandas de pistoleros que diezmaban nuestra militancia" 4.

En el 1923 se afilió a CNT en el Sindicato de Oficios Varios de Sardañola en Ripollet y en el 1936 ingresa en la FAl:

"...A mi me llamaban "Miss FAl", y yo ingresé en ella el día 21 de julio de 1936, cuando me dijeron: "Deberías ir al Comité Peninsular" y yo contesté: "Desgraciados, ¿cómo queréis que vaya al Comité Peninsular si no pertenezco ni a la FAl". Y entonces entré en ella y fui al Comité Peninsular ${ }^{5}$ ».

Véase el artículo, “Federica Montseny y la CNT-FAl», Historia y Vida, n90, Septiembre 1978.

Entrevista de PONS, A., "Federica Montseny, entre el recuerdo y la nostalgia " (I), Sábado Gráfico, 947, julio 1975

Ibíd.

MONTSENY, F., Mis primeros cuarenta años, Barcelona, Plaza y Janes, 1987, p. 33.

Entrevista de: PORCEL, B., "Federica Montseny, ayer y hoy" (II), Destino, Octubre 1976. 
La llegada de la II República tuvo para Federica Montseny una significación especial:

“...la libertad de miles de presos, la vuelta de exiliados y la posibilidad de abrir un periodo revolucionario que sobrepasase la simple instalación de un democracia burguesa" 6 .

Más tarde, con la llegada de la Guerra Civil, vendría uno de los momentos más importante en la vida de F. Montseny, ya que será la primera mujer que formaba parte de un Gobierno en España: de noviembre de 1936 hasta mayo de 1937 como ministra de Sanidad y Asistencia Social en el Gobierno del socialista Largo Caballero.

Terminada la guerra pasó la frontera con su familia y se exilió en Francia. Allí moririan sus padres:

«...mi madre cruzó la frontera en una camilla y murió el día cinco de febrero de 1939, en el hospital de Perpiñán. Y mi padre el día 12 de marzo de 1942 , en el pueblecito de la Borgoña en el que nos habían residenciado ${ }^{7}$ ".

Tras su entrada en Francia tendrá lugar la ocupación alemana. Federica estaba en zona ocupada, primero en el campo y más tarde en París. De este período dice:

«El período que se escalona entre 1942 y los últimos meses de 1944 fueron los más angustiosos, los más difíciles para nosotros (...) quedamos reducidos a vivir de nuestros propios medios (...) sin la solidaridad y el apoyo mutuo establecido entre todos los habitantes del pueblo y masías que lo constituían, hubiéramos muerto de hambre" ${ }^{8}$.

Es apresada por las autoridades francesas y entra en la cárcel. El régimen franquista pediria su extradición, que fue denegada a causa de su embarazo.

En 1945 se instaló definitivamente en Toulouse. Con la Transición española volvió a España en 1977 y aunque continuó teniendo su domicilio en Francia, haría frecuentes visitas a nuestro país.

Falleció el 14 de Enero de 1994 en el hospital de la Gardelle, en Toulouse, y fue enterrada en el cementerio de Saint Cyprien, de la misma localidad francesa.

La figura de Federica Montseny ha sufrido, como tantos otros personajes públicos, la Memoria y el Olvido sobre su actuación en la historia. Dos han sido los momentos más importantes en su vida pública; por orden cronológico: la ocupación del Ministerio de Sanidad ,en tiempos de la Guerra Civil, y su papel de dirigente anarquista en el exilio.

\footnotetext{
MONTSEny, F., Mis primeros cuarenta años, Barcelona, Plaza y Janes, 1987, p. 55.

Entrevista de PONS, A., "Federica Montseny, entre el recuerdo y la nostalgia»"(I), Sábado Gráfico, 947, julio 1975.

8 Montseny, F., Seis años de mi vida 1939-1945, Barcelona, Galba, 1978, p. 214.
} 
Partiré desde el momento del exilio para analizar cómo la imagen de Federica Montseny ha sido tratada y cómo, esa imagen, ha ido variando desde esos momentos hasta su muerte.

Utilizaré, para la época del exilio, la abundante literatura histórica y memorias de sus compañeros libertarios. Su paso por el Ministerio de Sanidad será especialmente valorado con la llegada de la Transición, momento en el que se la hacen multitud de entrevistas, $y$, por último, veremos cual es su imagen pública con ocasión de su muerte.

\section{EL EXILIO}

Federica Montseny es un personaje extremadamente controvertido y polémico. Las primeras controversias sobre Federica, por su actuación en el exilio, vienen desde el inicio de este período; en primer lugar, por su actitud hacia los combatientes anarquistas $y$, en segundo lugar, por la formación y actuación del Consejo General del Movimiento Libertario.

Muchos de los libertarios que pasaron a Francia participaron en la Resistencia y en la lucha por la liberación del país vecino, entre ellos Francisco Pozán que organizaria una red de evasión y gracias a la cual muchos españoles salvaron la vida. Pero parece que todos los militantes no encontraban la actividad de Pozán tan positiva. Así, Germinal Esgleas, compañero de F. Montseny, los calificaba como «elementos indeseables y sospechosos" 9 .

Y, por lo tanto, había desautorizado su actuación en nombre del Consejo. Así lo afirmaba F. Montseny al escribir:

«Estos grupos (se refiere a los de Pozán y otros) habían sido condenados por los Comités orgánicos que representaban la parte más numerosa de la organización, estimando que no se podía, ni se debia, servir a fuerzas ajenas a las que representaban los intereses colectivos de la emigración y los particulares, ideales y políticos, de la organización obrera a la cual pertenecían" ${ }^{10}$.

A pesar de esta aseveración, F. Montseny, al hablar de Pozán en sus memorias, dice:

"...Francisco Pozán, conocido en la resistencia como "Vidal" (...) fue un hombre de una inteligencia y de un arrojo excepcionales. Verdadera figura de leyenda, digna de constituir el centro de una extraordinaria epopeya (...) A pesar de que la organización, en plenos clandestinos, tomara el acuerdo de abstenerse de mezclarse en las luchas que se libraron en Francia, fueron innumerables los compañeros que intervinieron en ella,..." "1.

9 Borrás, J., Políticas de los exiliados españoles 1944-1950, Chatillon-sous-Bagneux, Ruedo Ibérico, 1976, p. 206.

10 Ibid., pp. 206-207.

11 MONTSENY, F., Seis años de mi vida 1939-1945, Barcelona, Galba, 1978, pp. 223/224. 
Estos Comités Orgánicos, a los que se refiere Federica, son, en definitiva, el Consejo General del Movimiento Libertario, que se fundara en los primeros días del exilio, exactamente el 25 de febrero de 1939, en París, con lo cual quedaban disueltos todos los comités anteriores. Este Consejo estaba compuesto por representantes de CNT, FAI y Juventudes Libertarias. Entre sus miembros estaba F. Montseny:

«...me encontré con que el Consejo General del Movimiento Libertario, constituido por representantes de todos los comités refugiados en Francia: Peninsular de la FAI, Nacional de la CNT, y Peninsular de la FIJ, nos habian designado a Peiró y a mi; a él para representar a la CNT en la JARE y a mi en el SERE 12 (...) Germinal junto con Mariano R. Vázquez (Marianet), se ocupaban de resolver los ingentes problemas que representaban los miles de refugiados..." ${ }^{13}$.

Con respecto al Consejo, Fidel Miró apunta que en las primeras reuniones no estuvieron todos sus componentes y que surgieron las primeras divergencias al estar F. Montseny en el SERE:

“Me tocó, en efecto, levantar las actas de las primeras reuniones del Consejo, antes de mi viaje a Suiza, y puede afirmar que en ninguna ocasión estuvo reunido el Consejo en pleno; por una u otra circunstancia nunca fuimos más de cinco o seis los delegados asistentes. Tampoco recuerdo que en alguna de aquellas reuniones estuviera presente Federica (...) En el SERE la representación del Movimiento Libertario la ostentaba Federica, en tanto que en el JARE nuestro representante lo era Juan Peiró. Tal situación empezó a producir una cierta división en la masa española exiliada. De ahí que, al no estar de acuerdo con nuestra presencia en el SERE dirigí, a mi regreso de Suiza, una carta a Germinal Esgleas, (...) comunicándole mi dimisión del cargo de vocal..." ${ }^{14}$.

Precisamente sobre su actuación en el SERE, y ante las críticas de sus compañeros, Federica hará las siguientes puntualizaciones:

"...Aunque muchos lo hayan puesto en duda, ni por un momento pensé en aprovechar las ventajas de la situación que ocupara en el SERE para ponernos a salvo, ni yo ni mi familia" 15 .

Con relación al Comité algunos militantes ponen en entredicho su formación, actividad y representatividad. Para José Borrás hay que diferen-

12 Las fuerzas políticas exiliadas se dividieron en el SERE, orientada por Negrin, y la JARE, orientada por Prieto.

13 Montseny, F., Mis primeros cuarenta años, Barcelona, Plaza y Janés, 1987, pp. 147-148.

14 Mıró, F., Anarquismo y Anarquistas, Editores Mexicano Unidos, S.A., 1979, pp. 212-213.

is Montseny, F., Mis primeros cuarenta años, Barcelona, Plaza y Janés, 1987, p. 151. 
ciar entre la organización Oficial y la Real del Movimiento Libertario en el exilio, por lo menos hasta avanzado el año 1944. Borrás llama organización Oficial al Consejo General del Movimiento Libertario y es muy crítico con su formación:

"Llamamos organización oficial al Consejo General del Movimiento Libertario creado en París por decisión de CN de la CNT, los Peninsulares de la FAl y de la FIJL y algún encopetado militante que por entonces - febrero de 1939 - pululaba por la capital francesa. Vale decir que para tal decisión, no disponían de ningún mandato de la base (...) Por unas u otras causas, a partir de 1942-43, la composición de este organismo quedó reducida a las personas de Esgleas y Montseny" ${ }^{16}$.

Y es todavía más crítico referente a su actividad y representatividad:

«...¿Cuál era su objeto? Según se declaraba en la primera circular del Consejo, fechada en París el 25 de Febrero de 1939, el organismo se creaba: "para salvaguardar los valores morales y materiales del Movimiento". Más en nota al pie de la circular se precisaba: "A partir de la fecha, la representación del Movimiento Libertario y de las organizaciones que lo componen, la asume totalmente este Consejo, no debiendo atenerse lo que del mismo no proceda". Esta representatividad no se apoyaba en ninguna estructura. Tampoco traslucía de ese organismo ningún programa de acción en ningún sentido. $Y$ en realidad eso fue el Consejo: un fantoche "representativo", una verdadera entelequia, sin contactos con la base y sin actividad" 17.

José Borrás llama organización Real a la que se creó en los campos de concentración, en la Presa de L’Aigle (Cantal), en Berziers, en Montpellier, en Marseille y en muchos otros lugares. Los fines de éstos fueron la necesidad de agruparse, de estar organizados, de solidaridad, de cómo ayudar a los compañeros que se habían quedado en España y salvar la vida a muchos militantes que estaban condenados a muerte, etc. A este respecto, Enrique Marco Nadal cuenta cómo la organización del interior pidió ayuda al Consejo y cuál fue la actitud de éste:

“...Génesis López quien continuó viaje hasta París, para entrevistarse con la representación del Consejo del MLE-CNT y hacerle entrega del informe escrito (...) Tres días más tarde, regresó Génesis López diciéndonos que su entrevista con Federica Montseny, en presencia de su compañero Germinal Esgleas como representante del movimiento libertario en el exilio, había sido breve y fría (...) diciéndole al acabar de leerlo que, sintiéndolo

16 VV.AA, La oposición libertaria al régimen de Franco, 1936-1975, Madrid, Fundación Salvador Seguí, 1993, pp. 390-391.

17 lbíd., p. 391. 
mucho, el movimiento libertario en el exterior no podía hacerse cargo de la petición que le formulaba España debido a no disponer de medios económicos y que lo único que podía hacer era entregarle diez mil francos a él para que regresara a España e informase de lo que había o para abrirse paso en Francia, si decidía quedarse y que la decisión era cosa personal (...) que él volvía a España para informar al Comité Nacional del Interior del abandono en que la emigración dejaba a la militancia de España» ${ }^{18}$.

\section{A este respecto otro antiguo militante, Ramón Alvarez dice:}

"Ya hemos señalado que, muerto Marianet, (junio 1939), Secretario del Comité Nacional de la CNT y del Consejo General del Movimiento Libertario, no hubo asistencia económica ni colaboración de ninguna índole con la Organización de España. Para situar responsabilidades diremos que nos estamos refiriendo, de modo muy concreto, a Germinal Esgleas - Federica Montseny. El comienzo de la estrecha hermandad y de la ayuda incondicional del Exilio hay que situarlo en el año 1944, ya vencido el nazismo y actuando a la luz del día la CNT que se habia organizado al margen de los representantes del desaparecido Consejo General» ${ }^{19}$.

Con respecto a la actuación del Consejo, Abel Paz, militante cenetista, pone el acento en la situación que se viviría con la llegada de la segunda guerra mundial:

"Ya hemos hablado del Consejo del Movimiento Libertario que se constituyó en París, inmediatamente después de la pérdida de Barcelona en febrero de 1939. Desde Febrero de 1939 hasta la ocupación militar de Francia, este Consejo General del MLE en el exilio, mal que bien mantuvo relaciones más o menos directas con los militantes desperdigados por Francia (...) La época más activa del Consejo fue desde febrero a septiembre de 1939. En este periodo las relaciones con los comités de los campos de concentración fue más o menos asidua, al igual que con la CNT que se reorganizaba en España. Pero estas relaciones comenzaron a hacerse difíciles después de la declaración de la segunda guerra mundial "que dispersó a los cuatro vientos tanto a los miembros del Consejo como a los militantes" "20.

Los diferentes grupos de militantes libertarios fueron organizándose, y al mismo tiempo sintieron la necesidad de reunirse y evitar así una fragmentación mayor; con este motivo se celebró una reunión en Marsella, un Pleno de regionales, en diciembre de 1943. En este Pleno, la Comisión de relaciones, que venía actuando encabezada por Juan Manuel Molina (Juanel),

Ibíd., pp. 100-101.

Ibíd., p. 332.

PAZ, A., CNT 1939/1951, Barcelona, Hacer, 1982, pp. 106-107. 
fue ratificada en sus funciones y recibió el encargo de organizar un nuevo Pleno de regionales.

Dicho Pleno se celebraría en Muret, el 22 de marzo de 1944; en él se tomarían, entre otros, los siguientes acuerdos: fusionar los comités a nivel nacional, reafirmar principios y tácticas, proseguir las relaciones con la UGT, nombrar un Comité representativo del conjunto libertario, crear una cuota mensual de 35 francos por afiliado y crear en zona ocupada un Subcomité nacional.

Ya en este momento había diferentes cuestiones que dividian a los libertarios en el exilio, formando dos grupos. Por un lado, los "posibilistas" o "reformistas" a favor de intervenir en la Resistencia de forma activa, tanto en Francia como en España; estaban a favor de establecer relaciones con otros sectores antifascistas en España y se remitian a las decisiones del CN de la CNT en España. La otra tendencia, la formaban los «maximalistas» u "ortodoxos», entre los que estaba F. Montseny, que jugaban la carta revolucionaria, estaban alejados de la Resistencia activa y querían ratificar principios, tácticas y finalidades del Movimiento Libertario y preparar el terreno para un levantamiento popular en España.

EI CN que surgió del Pleno de Muret, convocó un Pleno Nacional de regionales que se celebró en Toulouse en octubre de 1944. En este Pleno se tomaban, entre otros, los siguientes acuerdos: la colaboración con otros elementos antifascistas, en concreto, con los que lucharon en el período 1936-1939 para derrocar a Franco y, participar en los gobiernos que apoyasen las reivindicaciones de 1936-1939.

Estos acuerdos crearian una gran polémica, provocando un fuerte enfrentamiento entre los "reformistas" y los "ortodoxos" que rechazaban el punto tercero en el que el Movimiento se declaraba dispuesto a participar en el gobierno. Esta situación iba a estar en la base de la futura escisión de la CNT. Y desde este momento, la figura de Federica Montseny, junto con la de su compañero Germinal Esgleas, que encabezaban el grupo «ortodoxo», será duramente tratada por un gran número de militantes libertarios.

El Pleno de Octubre ratificaba el acuerdo del Pleno de Cantal de junio de 1943, que decía:

"Mientras los miembros que formaron parte del Consejo General del MLE no diesen cuenta de su gestión y ésta fuese aprobada por la organización, quedasen incapacitados para ocupar cargos orgánicos" 21.

21 Ibid, p. 114. 
Los «ortodoxos» lanzarían una campaña contra la resolución de participar en el gobierno republicano a través de "Ruta", que se editaba en Marsella y era el medio de difusión de las JJLL, y de "Impulso", de FAl, que se editaba en Toulouse:

“Esa campaña de prensa debió alcanzar tales tonos, que el CN del MLE, hizo publicar una nota en CNT de fecha 27 de enero de 1945, en la que, tras precisar que los órganos de expresión del Movimiento eran: CNT, Solidaridad Obrera (...) concluía así: "Ante la confusión creada por la aparición de tanta publicación al margen de las actividades orgánicas, el Comité Nacional recomienda la adquisición de las publicaciones mencionadas. Las demás (...) corresponden a iniciativas particulares"» 22 .

Los enfrentamientos iban a más en el seno del Movimiento Libertario, agravados con los problemas que planteaba la doble representatividad debida a la existencia del Consejo, que volvía a aparecer. La plenaria del $\mathrm{CN}$, creyó necesario la celebración de un Congreso de Federaciones Locales, que se fijó para el 1ํ de mayo de 1945.

Los prolegómenos del Congreso son de alta tensión como se puede ver en la declaraciones que hacen los militantes, divididos en dos grupos: los que ven la mano de Montseny-Esgleas manipulando todo lo posible en la preparación del Congreso, y los que atribuyen la misma actitud a los miembros del $\mathrm{CN}$.

Así, José Borrás ve como según se va acercando el Congreso:

«...empezaron a perfilarse actitudes y a adoptarse posiciones que no dudaremos en calificar de interesadas. Por ejemplo a finales de 1944 (...) entra en escena orgánica Germinal Esgleas, queriendo hacer valer sus títulos de secretario general del Consejo General del Movimiento (...) y plantea una serie de condiciones, mediante la aceptación de las cuales, se avendria a incorporarse a la organización (...) Por otra parte, en el mes de marzo de 1945, sin que hasta entonces hubiese dado signos de vida, entró en escena de manera pública y orgánica otra personalidad de talla: Federica Montseny. Esta pronuncia conferencias, interviene en mítines y escribe artículos en la prensa sabre lo 'accidental y lo permanente en la CNT'(...) no faltaba, como es natural - aunque divulgada con mayor discreción - la consabida candidatura para los cargos del Comité nacional, en el que iban incluidos los nombres de Germinal Esgleas y Federica Montseny" ${ }^{23}$.

El mismo Borrás en su libro, de reciente aparición, Del Radical-Socialismo al Socialismo Radical y Libertario, es todavía más concluyente:

22 Borrás, J., Políticas de los exiliados españoles 1944-1950, Chatillon-sous-Bagneux, Ruedo Ibérico, 1976, p. 217.

23 Ibid., pp. 220-221. 
"...Eso sin olvidar, por supuesto, dado que era el objetivo central, la circulación de la consiguiente candidatura para ocupar los cargos del Comité Nacional. Todo funcionaba a pedir de boca pero el MLE-CNT en Francia se hallaba manipulado sin darse cuenta. Una manipulación cuyos hilos no manejaban los hombres que daban la cara, sino otros que permanecían ocultos, como ocurre con frecuencia en estos casos, y que se hallaban bien situados para, aprovechando la situación, encaramarse en los puestos clave de la organización, para vivir de ellos puesto que eran retribuidos. Me estoy refiriendo, no quiero ocultarlo, a Germinal Esgleas y Federica Montseny» ${ }^{24}$.

Ramón Alvarez también tiene una visión semejante a la de Borrás pero, si cabe, con matices más duros, ya que habla de "estrategia de fraude", «invención de Federaciones locales» o «votos fantasmas»:

"Los dos miembros se atribuyeron la representación del Consejo - Germinal Esgleas y Federica Montseny - los que habian concitado la unánime repulsa por su inhibición en los difíciles años de la ocupación nazi, fueron recuperando influencia con el apoyo de "pescadores de río revuelto", que nunca faltan, y las medianías que utilizan siempre, para destacar el lenguaje de la violencia como filosofía revolucionaria, los actos violentos y las extravagancias. Bastante militancia cayó en las redes de la estrategia del fraude, colaborando a la invención pura y simple de Federaciones Locales o fundándolas con individualidades dispersas por los más apartados rincones de Francia, convirtiéndolas en fuente de votos fantasma, pero que se contabilizaron, permitiendo dominar el Congreso, hacer triunfar la candidatura previamente elaborada, para ejercer, más tarde desde los cargos, una descarada dictadura, apartando a todos los críticos» 25.

La visión de Abel Paz es bastante diferente a la manifestada por los anteriores militantes. En primer lugar, en cuanto a las responsabilidades que el CN exigía a los miembros del Consejo:

"Es curioso que se libere de responsabilidades a Horacio Prieto habiendo pertenecido también al Consejo, sin esperar las conclusiones finales. También es curioso que se dejen de lado a los otros miembros, tales como Valerio Más y Pedro Herrera, y que sólo se pida responsabilidades a Germinal Esgleas por inoperancia del Consejo, cuando desde la entrada de los alemanes hasta la liberación de Francia estuvo preso. Pensamos que a través de la persona de Germinal Esgleas lo que se quería invalidar era la tendencia extremista de la CNT» ${ }^{26}$.

24 BorRás, J., Del Radical-Socialismo al Socialismo Radical y Libertario, Madrid, Fundación Salvador Seguí, 1998, p. 110.

25 VV.AA., La oposición libertaria al régimen de Franco 1936-1975, Madrid, Fundación Salvador Seguí, 1993, pp. 312-313.

26 PAZ, A., CNT 1939-1951, Barcelona, Hacer, 1982, p. 123, nota 32. 
En segundo lugar, al referirse a la preparación del Congreso. Paz pertenece al grupo que ve la mano del $\mathrm{CN}$ en la manipulación del Congreso de París:

\begin{abstract}
"Desde el momento en que el Comité Nacional del MLE en el exilio tomó conciencia de que la celebración de un Congreso sería definitivo para fijar la línea a seguir, utilizó todos los resortes del aparato y sus órganos de prensa para influir en la base a favor de la adopción de una actitud política realista y acorde con la esperanza que aún se tenia en las democracias (...) el Comité Nacional y los militantes que compartian su linea política, consideraban que la CNT debía seguir siendo una fuerza gubernamental y una garantía de orden. Una posición diferente, es decir, una vuelta a las fuentes clásicas y revolucionarias de la CNT tenia que perjudicar forzosamente la estrategia política que el Comité Nacional defendía contra viento y marea» ${ }^{27}$.
\end{abstract}

El Congreso se celebraría en el Palacio de la Química, en el mes de mayo, en París. Asistirían los delegados que representaban a unos 30.000 afiliados. Los enfrentamientos, como era de esperar, se produjeron entre las dos fracciones: los que pensaban que el colaboracionismo abierto en 1936 estaba vigente y los que querían una vuelta hacía principios anarquistas más "puros". Las dos partes se hicieron concesiones para evitar la escisión:

"Desde un principio, pesó sobre él (se refiere al Congreso) como espada de Damocles el peligro de la escisión y, en aras de evitarla, las fracciones representadas se hicieron concesiones mutuas. Pero unos y otros se engañaron porque la escisión era inevitable, estaba latente entre los militantes y sólo faltaba materializarla" ${ }^{28}$.

Las decisiones del Congreso, como se ha dicho, reflejaban la intención de todos de evitar la escisión, por lo que se transigía para intentar que un grupo no quedase por encima del otro. Pero para algunos militantes, como es el caso de Ramón Alvarez, la intransigencia de personas como Federica Montseny hacia los acuerdos difíciles:

«...el tema político, (...) la ponencia designada para estudiar el tema y presentar unas conclusiones sobre el particular, era numerosa. Yo formé parte de la misma. Después de mucho discutir, fue nombrada una pequeña Comisión que formalizase en un dictamen, el debate de la sesión plenaria. De los "buenos" estaban Esgleas, Federica y no recuerdo que otro. Domingo Torres, Horacio M. Prieto y yo representábamos a los "malos", a los "heréti-

27 Ibid., pp. 125-126.

28 Ibíd., p. 134. 
cos". Costó llegar a un acuerdo, pues Federica, cada vez que nosotros mostrábamos conformidad con algo - aunque propuesto por ella misma- le parecía asistir a un juego de fantasmas, y no vacilaba en echarlo todo a rodar " 29

\section{Y es que para Ramón Alvarez:}

"Este Congreso fue la primera maniobra realizada a niveles entonces insospechados en los medios confederales, dirigida por la pareja tantas veces señalada (se refiere a Esgleas Montseny) como responsable de las desgracias colectivas sufridas desde hace lustros" 30 .

En el Congreso se elegirán a los militantes que formarían el nuevo Comité Nacional, entre ellos Esgleas y Montseny. Como explica Borrás:

"El Congreso procedió también a la elección de cargos para el nuevo Comité Nacional. Para cierto número de militantes "encopetados", ése y no otro era el verdadero objeto de la batalla que se había librado antes y en el curso del congreso, disfrazándola con los ropajes de fidelidad a los principios, tácticas y finalidades clásicas, a fin de mejor sorprender la buena fe de infinidad de militantes de base" ${ }^{31}$.

«Entre los elegidos figuraban Germinal Esgleas y Federica Montseny. EI primero como Secretario General, nada menos. Al conocer el resultado del voto se armó nuevo tumulto. No faltaron las impugnaciones contra Germinal y Federica. Los impugnadores, aducian, no sin razón, que un pleno les había inhabilitado para desempeñar cargos, decisión revocada por una plenaria sin estar calificada para hacerlo. El forcejeo se prolongó durante algunas horas, pero los impugnadores se quedaron con la razón, Germinal y Federica con los cargos» ${ }^{32}$.

Para Borrás lo justo, tal y como estaba transcurriendo el Congreso, era que los representantes de una y otra fracción, por honestidad, se alejasen de los cargos representativos; ello contribuiría a fomentar la concordia entre los militantes. Así:

“...Juanel que era, a la sazón, secretario general del Comité Nacional, encabezaba una de las tendencias. Germinal Esgleas y Federica Montseny encabezaban la otra. Juanel declaró públicamente en varias ocasiones y con

\footnotetext{
29 Álvarez, R., Historia negra de una crisis libertaria, México, Editores Mexicanos Unidos, 1982, pp. 112-113.

${ }^{30}$ Ibid., p. 105.

${ }^{31}$ Borrás, J., Políticas de los exiliados españoles 1944-1950, Chatillon-sous-Bagneux, Ruedo Ibérico, 1976, p. 226.

32 VV.AA., La oposición libertaria al régimen de Franco 1936-1975, Madrid, Fundación Salvador Segui, 1993, p. 397.
} 
anterioridad al congreso, que no aceptarian el cargo que ocupaban, ni ningún otro, en caso de ser elegido. Germinal Esgleas y Federica Montseny, por el contrario, aceptaron que sus nombres fuese incluidos en la candidatura a que hemos aludido, a fin de acceder a esos cargos" ${ }^{33}$.

Como hemos visto, las críticas por la actuación de Federica Montseny y su compañero Germinal Esgleas, tanto por su actividad en el Consejo como en la preparación y posterior desarrollo del Congreso de París, son, en general, muy duras. Pero éstas se redoblan a la hora de enjuiciar su actuación en la elección de militantes libertarios para ocupar los puestos en el Gobierno del Dr. José Giral en 1945.

En México, en agosto de 1945, fue elegido como Presidente de la República Española, Martínez Barrios, y presentó su dimisión, como Presidente del Gobierno, Juan Negrín. El Dr. Giral sería el encargado de formar el primer gobierno en el exilio. Para muchos antiguos militantes, la participación de la CNT en dicho gobierno sería el detonante de la escisión que se venía gestando desde tiempo atrás.

Giral pediría al Movimiento Libertario que le propusiera cuatro nombres, entre los que él elegiría a dos para incluirlos en el gobierno. En un principio, será la CNT de México la que aportará diferentes nombres; pero al no llegar a un acuerdo:

"...Entonces Giral manifestó que la propuesta de ministros debía se hecha por el Comité Nacional de la CNT clandestina de España. Éste así lo hizo, designando a tal fin a José Sancho, José E. Leiva, Federica Montseny y Horacio $M$. Prieto. Los dos primeros residian en España, los dos segundos en el exilio (Francia). Esa propuesta fue cursada a México por conducto del Comité Nacional de la CNT de Francia, del que eran cabezas visibles Germinal Esgleas y Federica Montseny, quien la transmitió a Giral sin poner el menor reparo. Pero Giral tuvo la mala ocurrencia de retener como ministros los nombres de Horacio M. Prieto y José E. Leiva” ${ }^{34}$.

Otra versión sobre la elección de los ministros cenetistas por parte de Giral nos la ofrece el propio Borrás:

"Sobre esta incidencia existe otra versión. Es la que el Comité nacional dio en la plenaria extraordinaria, al quejarse de que el Comité nacional de España no hubiese realizado los trámites de esta gestión por el canal del Comité

33 Borá̇s, J., Políticas de los exiliados españoles 1944-1950, Chatillon-sous-Bagneux, Ruedo Ibérico, 1976, p. 227.

34 Borras, J., Del Radical-Socialismo al Socialismo Radical y Libertario, Madrid, Fundación Salvador Seguí, 1998, p. 116. 
nacional de Francia, como venía haciendo, sino por el de la delegación de México» 35 ,

\section{Aunque termina diciendo:}

"Hechas por nuestra parte las averiguaciones de rigor, nos encontramos con que la versión de Ramón Alvarez (es decir, la primera) ofrece todas las garantías de autenticidad" ${ }^{36}$.

Versión diferente, al menos en el desenlace, ofrece Abel Paz en su libro; quien, en un primer momento, cuenta como Giral se pone en contacto con la CNT en México para nombrar a los ministros; pero el sindicato no está de acuerdo con la proporcionalidad que se le quería atribuir en el futuro gobierno $y$ :

«...después de muchos regateos, Giral aceptó dar dos carteras, pero a condición sine qua non de que se le presentara una lista de cinco nombres entre los cuales él elegiría dos" ${ }^{37}$.

Según Abel Paz, La CNT de México nombraría a dos compañeros directamente; pero esto no fue aceptado por Giral que mantenía su posición de exigir una lista. Los compañeros de México remitieron la petición a la CNT de España para que fuera ésta la que mandara los nombres de los futuros ministros. Y es, en este punto, cuando la versión de Abel Paz difiere completamente del resto; ya que, sin hacer más mención a la famosa lista, dice como el Comité Nacional de España elige a los ministros:

«El pleito entre Giral y la CNT quedó resuelto cuando el Comité Nacional de la CNT de España nombró a José Expósito Leiva para la cartera de Agricultura y a Horacio Martínez Prieto para la de Obras Públicas » ${ }^{38}$.

La elección de los nombres elegidos por Giral para su gobierno o, mejor dicho, la no elección de Federica Montseny fue, según la opinión de un grupo de militantes, como veremos a continuación, la causa determinante para que se produjera la escisión en la CNT. Así Enrique Marco Nadal dice:

“...Giral eligió a Leiva y Horacio M. Prieto desestimando a Sancho y a Federica Montseny quien al verse excluida, a pesar de haber sido la mediadora

\footnotetext{
35 Borrás, J., Políticas de los exiliados españoles 1944-1950, Chatilion-sous-Bagneux, Ruedo Ibérico, 1976, p. 241.

36 lbíd., p. 241.

37 PAZ, A., CNT 1939-1951, Barcelona, Hacer, 1982, p. 147.

38 Ibíd., pp. 147-148.
} 
entre el Comité Nacional del interior y el señor Giral, reaccionando como un cuadrúpedo en vez de cómo un ser humano, enfrentó a la Organización del exilio con la del Interior y, después de intentar hacer desistir al Comité Nacional del Interior de su acuerdo, procedió a la publicación de una nota dirigida a la opinión pública y para conocimiento del señor Giral, en la que se decía: "Los dos ministros que decían representar a la CNT no representaban a nadie, puesto que se trataba de dos extrabajadores sin representación orgánica, que sólo se representaban a sí mismos"» ${ }^{39}$.

“...el Comité Nacional de Francia cuya Secretaría General ostentaba Germinal Esgleas (...) que ninguna objeción hizo durante la tramitación al Comité Nacional del Interior (...) en nombre de los sacrosantos principios ácratas de los que siempre se han considerado ser la encarnación personal y han dejado de respetar cuando les ha convenido como hubieran hecho una vez más de haber tenido el Dr. Giral el desagradable gusto de aceptar a Federica en vez de rechazarla..." ${ }^{40}$.

José Borrás hace una interpretación en la misma línea:

"Giral tuvo la mala ocurrencia de retener como ministros los nombres de José $E$ Leiva y Horacio $M$. Prieto. Tan pronto como se supo que Federica no iba a ser ministro, el CN del MLE-CNT en Francia echó las campanas al vuelo y convocó telegráficamente una Plenaria, a fin de examinar la situación creada por el nombramiento de ministros de la CNT» ${ }^{41}$.

En parecidos términos se manifiesta Fidel Miró:

"De alguna manera la división o escisión estaba estrechamente relacionada con las divergencias ideológicas y tácticas existentes en la CNT desde mucho antes de nuestra guerra civil; era la continuación sistemática de la clásica división entre moderados y radicales, posibilistas y maximalistas; (...) Pese a todo, es opinión muy generalizada que la escisión no se habría producido de haber sido Federica Montseny designada para ocupar un ministerio en el Gobierno Giral» ${ }^{4}$.

"...la división en el exilio de la CNT en "colaboracionistas" y "anarquistas puros", que posiblemente se hubiera evitado si para ocupar los dos ministerios 'hubiesen sido designados Federica Montseny y Juan García Oliver" ${ }^{43}$.

39 VV.AA., La oposición libertaria al régimen de Franco 1936-1975, Madrid, Fundación Salvador Segui, 1993, p. 103.

40 Marco NadAl, E., Todos contra Franco. La ANFD 1944-1947, Madrid, Queimada Ediciones, 1982 , p. 38.

4) VV.AA., La oposición libertaria al régimen de Franco 1936-1975, Madrid, Fundación Salvador Segui, 1993, p. 398.

42 Miró, F., Anarquismo y Anarquistas, Editores Mexicanos Unidos, 1979, p. 215.

43 Mıro, F., ¿Y España Cuándo?, México, Editorial B. Costa Amic, 1959, p. 37. 
La desautorización de los dos ministros por parte del CN de Francia ponía en una situación difícil al $\mathrm{CN}$ de España. Un grupo de militantes lanzaron un manifiesto: "Con España o contra España", firmado por todas las regionales de origen de la CNT en Francia. En él se impugnaba y se negaba la representatividad al CN de Francia y se proponía la creación de otro CN de acuerdo con España. Con lo cual, la escisión dentro del Movimiento Libertario era inevitable; materializándose en diciembre de 1945:

"La grave situación creada exigía la celebración de un congreso de toda la organización (...) con muchos menos motivos se habia convocado el de París. Pero no señor. Los responsables de la rue de Belfort (residencia del $\mathrm{CN}$ de Francia) prefirieron que cada una de las doce regionales celebrase su congresito por separado. ¿Para mejor controlar su desarrollo y sus decisiones? Posiblemente. Rompió el fuego la Regional no 2 (Toulouse), donde residía la flor y nata de la militancia libertaria, sin duda para marcar a las otras regionales la pauta a seguir. Y la marcó naturalmente. Allí se materializó la escisión. Este congresillo se celebró en Toulouse del uno al cinco de diciembre de 1945. En él se aprobó una moción en la que, tras aprobar los acuerdos de la Plenaria que desautorizaban al CN de España, se decia: 'Los firmantes del manifiesto 'Con España o contra España', asi como cuantos lo apoyaran, deben ser expulsados fulminantemente del MLE-CNT en Francia. No obstante, se concede un plazo de un mes a aquellos compañeros que lo hubiesen hecho de buena fe, para que se reintegren a sus respectivas Federaciones Locales. Pasando dicho plazo, todos quedarán incursos en la misma sanción". Los demás congresillos regionales ratificaron la misma postura. A partir de ese instante, el MLE-CNT en Francia - y por extensión todas las demás agrupaciones del exilio- quedaba escindido en dos bandos desiguales" ${ }^{44}$.

La fracción de Federica Montseny y Germinal Esgleas era mayoritaria en el exilio e intentaba preservar el «anarquismo puro»; eran los "apolíticos» $u$ "ortodoxos". Por el contrario, el otro grupo, que tenía mejor organización en España, eran los llamados "políticos» o «reformistas». Los primeros, en contra de la unidad sindical con UGT, de pactos con otras fuerzas democráticas, de cualquier participación política y a favor de la acción insurreccional y el activismo armado. Los segundos, a favor de los pactos con UGT, de cierta acción política y del pacto con otras fuerzas democráticas ${ }^{45}$.

El distanciamiento y el enfrentamiento entre las dos fracciones cenetistas se prolongaría durante quince años; hasta que en 1960-61 se producirá la

44 VV.AA., La oposición libertaria al régimen de Franco 1936-1975, Madrid, Fundación Salvador Seguí, 1993, p. 399.

45 Véase: MATEOS, A., Las izquierdas españolas desde la Guerra Civil hasta 1982, Madrid, UNED, 1997, p. 207. 
reunificación. Durante este período, no faltan las críticas hacia el sector que lideraba Federica Montseny con toda clase de acusaciones por parte de la otra fracción. Como las que hacen Enrique Marco y Ramón Alvarez:

"...Tan intensa actividad desplegada en el Interior encorajinaba al exilio, cada día más contra la CNT del interior y los hombres que le daban vida, hasta el punto de que tanto en su prensa oficial, como en los mítines en que intervenía la "Excelentísima exMinistro, Doña Federica Montseny", llegó a decir en Decazeuville: "Que la CNT de España tenia sus secretarias en la comisarías de policia franquistas" " ${ }^{46}$.

"Los envíos de fondos a la Organización de España se inician por el Comité salido del Pleno Nacional celebrado en Toulouse, en el mes de octubre de 1944 (...) estas últimas entregas fueron consentidas con propósito de condicionar la actuación confederal dentro de España, como demuestra el hecho significativo de que no volveria a entregar más dinero el Comité de EsgleasMontseny (...) este Comité desautorizaría a la organización por decidir la intervención de la CNT en el gobierno del Dr. Giral. A partir de ahí, las importantes sumas recaudadas a través de la suscripción abierta con carácter permanente, titulada: "Pro-España oprimida", las empleaban en el envío a España de grupos encargados de "doblar" a la CNT o derribar sus comités" ${ }^{47}$.

Borrás presenta una situación algo diferente a la de sus dos compañeros:

"Al producirse la división orgánica en Francia la fracción "ortodoxa" quedó huérfana de base orgánica en el Interior. Siempre declaró, sin embargo, no haber roto con la organización de España y ser solidaria con los compañeros en lucha contra el régimen franquista. En este aspecto, las importantes sumas, recaudadas y empleadas a ese fin, prueban que no se trata de una afirmación gratuita (...) La verdad es, de todos modos, que la organización de España estaba del lado de la otra fracción. Por esta razón los "ortodoxos" se dedicaron de inmediato a enviar al Interior hombres y grupos con el fin de "recuperar" la CNT, "sin escindirla" ${ }^{48}$.

Hubo diversos intentos para que la escisión no se extendiera durante tan largo espacio de tiempo (quince años), pero los diferentes esfuerzos fueron inútiles. En muchos casos, se responsabiliza a la fracción «ortodoxa” del fracaso de estos intentos ${ }^{49}$. Algunos, como Fidel Miró, ven falta de interés en personas concretas:

46 VV.AA., La oposición libertaria al régimen de Franco 1936-1975, Madrid, Fundación Salvador Seguí, 1993, pp. 123-124.

47 lbíd., pp. 332-333.

48 Borras, J., Políticas de los exiliados españoles 1944-1950, Chatillon-sous-Bagneux, Ruedo Ibérico, 1976, p. 261.

49 Véase: Borrás, J., Políticas de los exiliados españoles 1944-1950, Chatillon-sous-Bagneux, Ruedo lbérico, 1976, pp. 258-261. 
"A partir de mediados de la década de los cincuenta, militantes de ambos sectores llevaron a cabo una serie de gestiones y actividades en aras de la reconciliación cenetista, pero en ninguna de estas gestiones y actividades anexas participó Federica Montseny" ${ }^{50}$.

La unificación se lograría en el segundo Congreso Intercontinental de Federaciones Locales, celebrado en Limoges, en el verano de 1961. Pero esta unificación no era todo lo fuerte que muchos militantes cenetistas deseaban. Algunos pensaban que más que una reunificación lo que había sucedido era que un grupo había vencido, el "ortodoxo", y el otro, el «reformista", había sido derrotado. También porque desde este momento el control de Federica Montseny y Germinal Esgleas iba a ser más férreo:

"..Las heridas producidas por la discordia no estaban restañadas todavía y no eran pocos los compañeros del antiguo sector "ortodoxo" que seguian empleando los términos ellos y nosotros (...) En el plano general, quiérase o no, se había operado, pura y simplemente, una integración de los "reformistas" a los "ortodoxos"" 51.

La opinión de Fidel Miró es muy similar pero, además, hace mención a la situación que se vive en esos momentos en las filas "ortodoxas»:

“La reunificación fue ciertamente muy endeble, pues, desde el primer momento, las discrepancias, sobre tácticas principalmente, prosiguieron y, en consecuencia, las dos tendencias continuaron enfrentadas ante cualquier problema o situación de alguna importancia. Más en honor a la verdad cabe señalar que muchos de los militantes más significados e inteligentes que habían estado hasta entonces al lado de Federica comenzaron a discrepar abiertamente respecto de su actitud intransigente, de su política de facción en el seno de la organización; de su predominio hegemónico, y con otras cosas, por lo que uno tras otro fueron seguidamente expulsados, entre ellos Peirats, Santamaria, Borrás y otros más" ${ }^{52}$.

Otros cenetistas no ven, en la reunificación, ningún interés sincero por parte de los dirigentes del grupo "ortodoxo". Más bien intereses particulares, como piensa Octavio Alberola Surinach:

“...El ambiente reflejaba el clima pasional que el sector "esgleísta" había creado en torno a la reunificación. No obstante, y a pesar de que algunos conspicuos militantes de la ex escisión hacian prueba de una igual intransi-

so Mıró, F., Anarquismo y Anarquistas, Editores Mexicano Unidos, S.A., 1979, p. 216.

5t Borfás, J., Del Radical-Socialismo al Socialismo Radical y Libertario, Madrid, Fundación Salvador Segui, 1998, p. 160.

52 Miro, F., Anarquismo y Anarquistas, Editores Mexicano Unidos, S.A., 1979, pp. 216-217. 
gencia y sectarismo, el Congreso siguió avanzando y acabó imponiéndose la dinámica unitaria, sobre todo a partir de la décima sesión (al comenzar esta sesión, Esgleas y Montseny sabian ya que habian salido elegidos para los cargos de secretario de la AIT y directora del periódico CNT respectivamente. Estos cargos eran retribuidos), que fue en la que el sector esgleísta se volvió más "conciliador"” 53

El período que siguió a la reunificación, parece que fue fructífero para el Movimiento Libertario, aunque esta etapa fue corta y se volvería a caer, otra vez, en la división:

"...se realizaban en aquel periodo 1960/1963 muchas otras actividades. Se había organizado un excelente servicio de información; se mantenían buenas relaciones con las Internacionales sindicales; funcionaba a pedir de boca la Alianza Sindical (...) la CNT no se encontraba aislada (...) Todo se fue al agua. Esa línea de actuación fue tachada de "reformista" y los compañeros que la aplicaban, relevados de sus cargos. Tras una campaña subterránea bien dirigida, Germinal Esgleas volvía a la brecha (...) Un ciclo prometedor y lleno de esperanzas quedaba cerrado. Se abría otro en el que, quizás sin proponérselo no hacían otra cosa que atizar las discordias y las divisiones internas y externas, dejando a la CNT exangüe y totalmente aislada" ${ }^{54}$.

En el Congreso, que se celebrará en Montpellier en 1965, la situación se agravó; hay duros enfrentamientos y 30 Federaciones Locales se retirarán de él. Meses después:

"...se hicieron públicas las conclusiones en cinco puntos, a que llegaron quienes, en nombre de un Comité Nacional de la CNT de España, establecieron diálogo con representantes del sindicalismo vertical. El Comité de la CNT en el exilio, dirigido por Esgleas emprendió una estruendosa campaña calificando de traidores a los cenetistas de interior que así procedieron (...) La operación les venía como anillo al dedo, pues así podian lanzarse a la "caza de brujas", meter en un mismo saco a todos los discrepantes y presentarse como los salvadores de la CNT (...) Aunque, no de forma orgánica, la CNT del exilio quedó nuevamente dividida, de hecho, y maltrecha» 55 .

No sólo es Borrás quien ve en la utilización, por parte de la cúpula de la organización, de las conversaciones entre los "cincopuntistas" y el sindicato vertical una excusa para proceder a una auténtica "caza de brujas»:

53 VV.AA., La oposición libertaria al régimen de Franco 1936-1975, Madrid, Fundación Salvador Segui, 1993, p. 361.

54 VV.AA., La oposición libertaria al régimen de Franco 1936-1975, Madrid, Fundación Salvador Seguí, 1993, pp. 405/407.

55 Véase: Borrás, J., Politicas de los exiliados españoles 1944-1950, Chatillon-sous-Bagneux, Ruedo lbérico, 1976, pp. 298-299. 
"Cuando el S. Intercontinental quería deshacerse de algún opositor molesto, ponía en circulación la especie de que apoyaba las "conversaciones"» ${ }^{56}$.

Los militantes, grupos y Federaciones Locales expulsados se unieron en una entidad llamada Grupos de Presencia Confederal y Libertaria. Estos grupos intentaban armonizar las diferentes tendencias que había dentro del movimiento libertario, así como mantener el contacto con otras organizaciones antifascistas en el exterior, para crear un frente común contra el régimen de Franco.

Por su parte, la CNT oficial del exilio seguiría con su ideología "ortodoxa", más preocupada por sus problemas internos:

«... metida en su cascarón, silenciosa e inmóvil, reduciendo su actitud a resolver problemas internos, a organizar mítines conmemorativos y a tomar alguna que otra resolución sobre España, puramente platónica. Sus actividades reales contra el franquismo, en cualquier terreno de actuación han brillado por su ausencia" 57 .

Esta CNT oficial, dirigida por el llamado Secretariado Intercontinental, controlará el movimiento libertario en el exilio bajo la batuta de Germinal y Federica:

«...A partir de 1963, el Secretariado Intercontinental se convirtió otra vez en monopolio de la "familia" (se refiere a la FAl), ya directamente, ya a través de vasallos escogidos en la base, mientras que casi todos los militantes de valor, expulsados, retirados por su propia voluntad o desconsiderados, quedaban separados de la masa de la diáspora confederal (...) el Secretariado Intercontinental (...) no publica más que lo que cree ortodoxo, sólo informa desde su punto de vista particular, excomulga a quien se le antoja, y trama lo que le parece... ${ }^{58}$.

Así, durante la segunda mitad de la década de los sesenta, muchos militantes, por diferentes motivos, y hasta Federaciones Locales son expulsados de la CNT; son los casos de José Peirats, Cipriano Mera, Octavio Alberola, Fernando Gómez, José Borrás...; y Federaciones Locales como la de Toulouse, Cougnaux y París ${ }^{59}$.

\footnotetext{
56 Álvarez, R., Historia negra de una crisis libertaria, México, Editores Mexicanos Unidos, 1982, p. 280.

57 Ibíd., p. 299.

58 LoREnzo, C.M., Los anarquistas españoles y el poder, París, Ruedo lbérico,1972, p. 322.

59 Véase: Borrás, J., Del Radical-Socialismo al Socialismo Radical y Libertario, Madrid, Fundación Salvador Seguí, 1998, pp. 202/204.
} 
La actuación del Secretariado Intercontinental es comparada, por militantes como Ramón Alvarez y José Borrás, con las formas de la «Inquísición» o las "purgas de Stalin»:

"Rompieron todo vínculo con las juventudes libertarias, expulsaron a caracterizados militantes, a Federaciones Locales como las de Toulouse y Cougnaux, cuando se opusieron a separar de sus filas a hombres señalados para el sacrificio porque estorbaban al S. Intercontinental y a cuantas resistian a las imposiciones de las alturas. La FAl seguía sumisamente la línea trazada desde el número 4 de la rue de Belfort por el "alto Tribunal del Santo Oficio" " ${ }^{60}$.

«...un tercio de los militantes de la CNT de España en el exilio quedaba así excluido de la organización. La hora de las purgas, como en otros tiempos en el antro de Stalin, había sonado en la CNT..." ${ }^{6 !}$.

Entrada la década de los 70 , todos los grupos opositores, al régimen franquista, fueron tomando posiciones ante la Transición democrática, que tendría lugar tras la muerte del dictador. La CNT no sabrá entender el momento histórico que se avecina:

“... la CNT se hallaba atomizada en diversas tendencias y a que, en ellas, se manifestaba la detestable manía de permanecer aislados, para no adquirir "compromisos"” 62.

Durante todo este tiempo, junto a su labor política en el sindicato e inseparable a ella, Federica seguirá escribiendo en la prensa confederal. Será jefa de redacción en «L'Espoir» de Toulouse, revista bilingüe, que sustituyó a "CNT» órgano del MLE-CNT en Francia.

Desde las páginas de “L'Espoir», a lo largo de los años 60,70 y 80 , hará un repaso a la actualidad del mundo, con especial atención a lo que acontece en España; dedicará artículos a personajes y acontecimientos de la historia.

Desde esta tribuna querrá mantener la denuncia contra el régimen franquista. Así, en su artículo: «Burgos sangriento: El proceso del franquismo", fechado el 20 de diciembre de 1970, dice:

"Lo importante de este proceso no es la personalidad de los encausados. Lo importante es que el proceso de Burgos resulta, ante el mundo, e incluso

60 Álvarez, R., Historia negra de una crisis libertaria, México, Editores Mexicanos Unidos, 1982, P. 292.

61 Borrás, J., Del Radical-Socialismo al Socialismo Radical y Libertario, Madrid, Fundación Salvador Seguí, 1998, p. 203.

62 Ibíd., p. 210. 
ante la opinión española, el proceso del régimen franquista, evidenciando una vez más, su ferocidad, el carácter de la dictadura, la catadura moral de los hombres que la ejercen y que la encarnan y que no ha variado en nada» ${ }^{63}$.

En otros momentos, hará su crítica a las formas de lucha, que ella interpreta equivocadas, como es el caso del joven Pallach, en Checoslovaquia, y de una serie de suicidios, que se están dando en la Europa del Este; como protesta por la ocupación rusa. Este episodio, lo contrapone a la actuación de los estudiantes en Madrid, donde tienen lugar duros enfrentamientos con la policía, en protesta por la dictadura franquista:

"...los estudiantes checoslovacos reaccionan con la amenaza de nuevos suicidios por el fuego. Los estudiantes españoles con otra concepción más dinámica y ardiente de la vida, por el momento no hablan de suicidarse, sino de defenderse atacando. (...) La lucha es sin cuartel y a muerte. Pero no nos dejemos seducir por esa llamada romántica de la Pálida... Para poder luchar, para poder ser útil en la lucha, hay que vivir..." ${ }^{64}$.

\section{FEDERICA MONTSENY EN LA TRANSICIÓN}

Tras la muerte de Franco, llegará la Transición a la democracia y con ella el fin del "Olvido oficial», es decir, el que fue impuesto, con relación a ciertos hechos o personas, por el poder político.

En estos años, aparecerán multitud de publicaciones que harán referencia a un pasado del que, hasta ese momento, solamente se había tenido una idea parcial de él. Dichas publicaciones buscarán a los personajes que han sobrevivido a la dictadura y se intentará recuperar, a través de la Memoria de estas personas, parte de la historia que no había sido contada.

Es el caso de Federica Montseny; a quien las revistas españolas dedicarán entrevistas y monografías.

El contenido de estas entrevistas está relacionado con los dos momentos sobre los que los españoles tenían especial interés en la transición: La II República y la Guerra Civil. Junto a estos dos grandes temas, se hará un repaso a la vida de Federica, desde su nacimiento hasta el fin de la Guerra Civil. Le pedirán su opinión sobre el momento que se estaba viviendo en España. También, se aprovecha, para informar al lector sobre

53 Artículo de F. Montseny, extraído de: ALCALDE, C., Federica Montseny palabra en rojo y negro, Barcelona, Editorial Argos Vergara, 1983, p. 189.

64 lbíd., pp. 178-179. 
los planteamientos teóricos del anarquismo y sobre las diferentes organizaciones libertarias.

Es interesante ver como el período del exilio, que ha supuesto cerca de cuarenta años y que, como hemos visto, fue época de grandes enfrentamientos entre los militantes libertarios, no es prácticamente mencionado.

En el presente trabajo, se han utilizado cuatro entrevistas, que se realizan a Federica Montseny entre los años 1975 y 1978, por las revistas Sábado Gráfico; Destino; Tiempo de Historia; e Historia y Vida.

En todas ellas, se empieza hablando de la familia Montseny y principalmente de la ideología de los padres. De cómo, ésta, influirá en la formación y futura actividad política de Federica. Se pone especial interés en el carácter luchador e intelectual de la familia. Su fama de intelectual será un referente continuo en su vida pública, así como en su militancia en la CNT:

En el prólogo de la entrevista que publica Sábado Gráfico, se dice:

«...Sus extraordinarios conocimientos intelectuales y su experiencia política le llevan a hacerse rápidamente cargo de las situaciones o problemas que se la plantean" ${ }^{65}$.

En general, se hacen preguntas sobre «la base ideológica de la CNT»; "¿Cuáles eran las relaciones entre la CNT y la FAl?"; "¿Qué opinión le merece Durruti?» u otros personajes de la época como Indalecio Prieto, Azaña o Companys.

Pero el referente principal, en las entrevistas, es que Federica Montseny ocupó un ministerio en el Gobierno de Largo Caballero durante la Guerra Civil, concretamente el de Salud Pública. Por una parte, se le pide una explicación sobre el porqué un militante anarquista ocupó un puesto en el Gobierno. Al mismo tiempo, hay una revalorización de su persona, al ser la primera mujer que en España ocupaba dicho cargo. Además, se pone especial énfasis en su labor al frente del Ministerio, principalmente, en aquellas actuaciones que tuvieron similitud con las que en este momento vive la España de la Transición:

P.: «En tu actuación al frente del Ministerio de Salud Pública, destaca una ley decretando la libertad del aborto. ¿Podrías ampliar este hecho, hoy candente en todos los paises europeos?" 66 .

65 Entrevista de Pons, A., «Federica Montseny, entre el recuerdo y la nostalgia» (I), Sábado Gráfico, 947, julio 1975.

so Entrevista del COLECTIVO FEBRERO, "Federica Montseny, una entrevista con la Historia», Tiempo de Historia, $\mathrm{n}^{\circ}$ 31, Junio 1977. 
P.: «Hablemos un poco de su permanencia al frente del Ministerio de Sanidad y de las circunstancias que le condujeron a aceptarlo. También sería interesante conocer la tarea concreta que hizo, por ejemplo en lo que se refiere a la promulgación de la Ley que permitía la interrupción del embarazo..." ${ }^{67}$.

Las referencias al exilio son muy escasas; solamente en la entrevista que se publica en Tiempo de Historia se habla de este período. Con lo reflejado anteriormente, en las opiniones de sus antiguos compañeros, bien merece la pena recoger alguna pregunta y su respuesta:

P.: “ ¿Cómo fue la marcha del Movimiento Libertario en el exilio y háblanos de las reestructuraciones que ha sufrido en esos años?"

F.M.: «Primero éramos Movimiento Libertario-CNT en el exilio. Fue cuando hubo la escisión, es decir, cuando una parte minoritaria decidió apoyar al Gobierno Giral y aceptar la intervención de Martínez Prieto y de José Leiva en representación de la CNT en ese gobierno. Poco tiempo después como ellos se reclamaban Movimiento Libertario-CNT, se decidió, según un Pleno Nacional de Regionales, cambiar el nombre y llamarse CNT de España en el Exilio, $y$ ése es el nombre que ha continuado hasta ahora. Cuando ellos reingresaron, en el Congreso de Limoges, la otra CNT se dio por disuelta y no hubo más" 68 .

Por último, en todas las entrevistas se hacia mención a la España de ese momento. Federica reflexiona sobre la situación política general que se está viviendo en España, y hace especial hincapié en el papel que, bajo su criterio, la CNT debería desempeñar. Federica sigue fiel a sus principios:

P.: «...Y dígame, ¿Cómo ve la situación española hoy y del inmediato mañana, qué papel cree que debe jugar la renacida CNT?"

F.M.: "Diria a la CNT que no acepte pactos ni compromisos.....la fuerza que se mantenga independiente, neutra, será la que se pondrá en la vanguardia de este descontento..." ${ }^{69}$.

En esta misma entrevista, contestando a la pregunta: “ ¿Volverá usted a Cataluña, a España?»; Federica Montseny muestra su disposición a la vuelta a nuestro país y, en su respuesta, polemizará con antiguos «compañeros»:

67 Entrevista de PONS, A., “Federica Montseny, entre el recuerdo y la nostalgia” (II), Sábado Gráfico, 948, julio 1975.

68 Entrevista del COLECTIVO FEBRERO, «Federica Montseny, una entrevista con la Historia", Tiempo de Historia, $\mathrm{n}^{\circ} 31$, Junio 1977.

69 Entrevista de: PORCEL, B., "Federica Montseny, ayer y hoy" (II), Destino, Octubre 1976. 
«...Hay también otra cosa que a mí me parece muy bien: toda esta juventud que tiene horror a los líderes y a los santones. Quien piense que con el prestigio del pasado o del exilio llegará a ser el líder, se equivoca (...) Eso de los jóvenes es una especie de rebelión de los hijos contra los padres. Yo lo creo positivo porque es la forma de evitar que estas "momias" que han vuelto del exilio, como Abad de Santillán, puedan meterse y conducir la CNT hacia donde ellos querrian..." 70 .

Estos antiguos "compañeros" seguirán, también en esta época, en sus libros y memorias, respondiendo y enfrentándose a Federica, como es el caso de Fidel Miró:

“...En fecha posterior -unos pocos meses después- a la muerte de Franco, al salir de un mitin celebrado en La Mutualité de París, con Federica como primera figura, un grupo de sus admiradores la rodearon y lo preguntaron qué opinaba de Diego Abad de Santillán, a lo que contestó con este exabrupto: "Santillán es un fósil". La pregunta se repitió de mi persona y ella contestó: "Este es un agente de la CIA".." ${ }^{71}$.

El mismo contestará a estas acusaciones, en una carta a Federica, con durísimos términos, entre otros:

"...Teniendo en cuenta su natural inclinación a la demagogia y la calumnia, no merecería el caso mayor atención (...) La contumacia en los insultos y despropósitos, el afán de alimentar un confusionismo disgregador y el obstinado empeño de lanzar cieno indiscriminadamente contra quienes tiene algo que decir y no se someten dócilmente a un gregarismo beato y a un imperativo de clan absorbente e inapelable (...) Ser tránsfuga y saltimbanqui, como en sus periodiquillos se afirma al referirse a mí y otros viejos militantes, no puede afectarme por cuanto llevo cincuenta años militando en una misma ideología, sin caer en sectarismos, fanatismos ni ortodoxias (...) La rectificación que le solicito se entiende como declaración explícita de que tales acusaciones, en especial la que se refiere a que soy agente de la CIA, son artificiosas, gratuitas y sin base alguna..." ${ }^{72}$.

Como vemos, en la época de la Transición, hay una gran diferencia entre la imagen que se trasmite de Federica Montseny desde las revistas españolas, y la que nos llega desde la perspectiva de algún militante cenetista.

Al margen de esta doble visión que se ofrece de Federica, según sea a través de la Memoria Colectiva o de la Memoria Histórica que se pretende

\footnotetext{
Ibíd.

Mıró, F., Anarquismo y Anarquistas, Editores Mexicano Unidos, S.A., 1979, p. 220.

Ibíd., pp. 221/223.
} 
recuperar, la actividad de la vieja militante cenetista seguirá su cauce normal, desde esta época hasta su muerte; continuará con su labor al frente del sindicato en el exilio y con sus publicaciones en la prensa confederal.

Para Margaret Torres, Doctora en Sociología con su tesis: El anarquismo viejo y nuevo: la reconstrucción de la CNT 1976-79, la labor de la CNT en el exilio, durante la Transición, fue muy importante para el devenir del movimiento libertario en España.

Para ella, la reconstrucción de la CNT, en ese momento, se hizo sobre dos vertientes: por un lado, "Sobre las fuerzas que se iban identificando con el anarquismo desde los años 70 en España, al margen de la CNT»; por otro, «con las fuerzas apoyadas por la organización exiliada de Toulouse» ${ }^{73}$.

Dentro de las primeras, hay que señalar a los grupos "Autónomos" que tenían una ideología marxista, pero llevaban a cabo una práctica anarquista; esto podía suponer el fin del enfrentamiento, entre anarquistas y comunistas, desde la Guerra Civil. La organización del exilio no estaba de acuerdo con el desarrollo del movimiento:

«... pasando por alto el movimiento autónomo, el exilio de Toulouse intentó crear "cuadros anarcosindicalistas" afiliados a la FAl, como punto de partida de la reconstrucción de la CNT en España. Sin embargo el éxito que tuvo fue mucho mayor entre estudiantes, (...) A pesar de que sus adictos en España fueron pocos, intentó controlar el proceso de reconstrucción de la CNT en España a partir de esa base” ${ }^{74}$.

Según la doctora Torres, la reconstrucción de la CNT se haría bajo dos tendencias: la que seguia fiel a los principios del Congreso de Zaragoza; y la que era proclive a revisar los principios y estrategias. Estos últimos veían la posibilidad de unir al movimiento libertario, otra serie de grupos de oprimidos como gays, mujeres, etc.

"Así que desde el principio la reconstrucción de la CNT se hizo sobre una ambigüedad -sindicato o movimiento libertario- una ambigüedad que dio al exilio la oportunidad de ejercer su influencia dentro de la CNT en España" ${ }^{75}$.

La llegada de cenetistas veteranos, en el 1976, fue primordial para el liderazgo del exilio en la CNT que se estaba reconstruyendo, e imponer su política faista:

73 VV.AA, La oposición libertaria al régimen de Franco, 1936-1975, Madrid, Fundación Salvador Seguí, 1993, p. 653.

74 ibid., p. 655.

75 lbíd., p. 658 . 
“...Esta política, como hemos visto, apoyaba su legítima defensa para mantener el control de la CNT sobre un fuerte sectarismo, un radicalismo "anti-estatal" verbal unido a una práctica "reformista", en resumen, una política carente de toda estrategia coherente para la CNT, aliada a la reclamación histórica de la FAl, la de ser "guardián anarquista" de la CNT» ${ }^{76}$.

Por lo tanto, en la Transición, como había pasado antes en el exilio, seguirán los enfrentamientos internos. Una vez más, se volverá a hablar de "expulsiones», «manipulación de congresos» y "tácticas violentas»:

«... la batalla dentro de la CNT en el año 78, que culminará en la expulsión de sindicatos enteros en el congreso de diciembre de 1979, un congreso manipulado para que la oposición no pudiera presentar su total condena de rol del exilio en España desde 1939. La capacidad "política" de la burocracia exiliada para mantener el control de la CNT fue posible por las tácticas "violentas" usadas contra las fuerzas a favor de una "nueva" CNT, pero también ayudaron las dificultades de montar la CNT como sindicato en el contexto del debilitamiento progresivo del movimiento obrero en los años 77 y $79 \ldots$. 77 .

En concreto, Federica Montseny hará su primer viaje a España en abril de 1977 , siendo ésta la primera vez que pisaba suelo español desde su salida hacia el exilio. Posteriormente, Federica hará frecuentes viajes a España hasta su muerte. El 1ำ de octubre de 1981 llegará a Madrid para aportar material del exilio:

«...documentos, libros y periódicos de un gran interés para el estudio del Movimiento Libertario y que constituía la herencia cultural de la CNT en el exilio. El objeto del traslado era crear la Fundación de Estudios Libertarios" ${ }^{78}$.

Federica participará, activamente, en los diferentes actos públicos que organiza la CNT en los años 80 . Así en febrero de 1985, tendrá un papel destacado en las jornadas de debate sindical, que se celebran en Barcelona, junto al que ese momento era el secretario general de la CNT, Juan Gómez Casas.

Intervendrá en un mitin en Barcelona, el 1 de noviembre de 1985, con motivo de la celebración del $75^{\circ}$ aniversario de la fundación de la CNT. Alli, aunque mermada, en su condición física, a causa de la ceguera, "pronunció un discurso tan vibrante como habitualmente»; en él, acusará a los políticos de «estar prostituidos", añadiendo:

\footnotetext{
lbíd., pp. 658-659.

lbíd, p. 673 .

78 Martin Morales, E., Federica Montseny, Barcelona, Labor, 1992, p. 55 (texto en catalán).
} 
«...ante la corrupción ambiente y el espectáculo vergonzoso de la España socialista, tan o más reaccionaria que la franquista, sólo queda la CNT como organización en defensa de los hombres y las ideas libres (...) cuando la clase obrera se de cuenta donde le han llevado los falsos pastores, volverá a apoyar al movimiento libertario" 79 .

El 1ㅇ de mayo de 1988, Federica Montseny participará en el acto que la CNT celebró en Barcelona, concretamente, en la Plaza de l'Escorxador. Federica, en su discurso, volverá a criticar la situación política del momento y mostrará su confianza en el resurgir del movimiento cenetista:

«En España, la situación es difícil porque hay una desmovilización de la clase obrera que los movimientos reformistas y de adaptación a la situación política permiten que prospere; así y todo, yo no pierdo la confianza en la recuperación de nuestra implantación popular " ${ }^{80}$.

El otro aspecto de la actividad de Federica Montseny, es decir, su labor al frente del semanario "L`Espoir", continuará, en la década de los 80, en la misma línea que se había desarrollado hasta estos momentos: con su preocupación especial sobre España, y prestando atención a los cambios que se están produciendo en nuestra sociedad.

En un artículo publicado en 1981, criticará la situación, que bajo su punto de vista, se está dando en la reciente democracia española, en la que los intereses personales se anteponen a los de la colectividad:

«El drama, precisamente, de esta España heredada del franquismo estriba en que nadie es capaz de asumir y afrontar tareas superiores, haciendo abstracción de ambiciones personales o sabiendo relegarlas a un segundo término. Nadie vive para una obra a realizar, en ninguno de los planos de la vida social y política. Todos viven para sobresalir, para imponerse, para protagonizar partidos, movimientos, empresas, sin un sentido colectivo" ${ }^{81}$.

En otro artículo, del mismo año, titulado: "las "conquistas" de la mujer", criticará, desde la ironía, la incorporación de la mujer a la Guardia Civil:

"Pero la última "conquista" de la mujer nos parece digna de ser destacada, pues se trataba de un cuerpo hasta ahora invulnerable a los asedios femeninos. A partir de esta fecha, la mujer en España, tendrá acceso al cuerpo de la Guardia Civil. (...) Esta última "conquista" de la mujer, en España

Ver El País, 2 de noviembre de 1985.

Martin Morales, E., Federica Montseny, Barcelona, Labor, 1992, p. 57

${ }^{81}$ Articulo de F. Montseny, extraido de: ALCALDE, C., Federica Montseny palabra en rojo y negro, Barcelona, Editorial Argos Vergara, 1983, p. 201. 
nos encanta. Era lo que faltaba para demostrar que una mujer vale un hombre en todos los sentidos..." ${ }^{82}$.

Utilizará el artículo para exponer su planteamiento respecto al feminismo y la liberación de la mujer:

«No hemos sido jamás ni feministas ni antifeministas. La liberación de la mujer y su derecho a ser en todo igual al hombre no tiene para nosotros vuelta de hoja. Si somos anarquistas es porque queremos la igualdad, la justicia, la libertad para todos. Y porque la mujer ha sido durante siglos oprimida y sojuzgada, sus reivindicaciones nos han parecido más que justas (...) Francamente, esta última "conquista" de la mujer nos parece detestable. ¡Sólo falta ahora que las gitanas se hagan guardias civiles!» ${ }^{83}$.

Sobre el mismo tema, años antes, escribía:

«Entre los muchos equivocos a desvanecer, hay el del sexo. Nosotros jamás hemos sido feministas, porque consideramos que la mujer debe tener los mismos derechos que el hombre y que, como el hombre, posee las mismas parecidas cualidades y los mismos semejantes defectos (...) Establecer un compartimento estanco entre hombres y mujeres, viejos y jóvenes, nos parece lo más absurdo y lo más estúpido..." ${ }^{84}$.

Federica irá distanciando, cada vez más, sus visitas a nuestro país, y preferirá morir en Toulouse, en "su exilio". Nunca entendió, del todo, a aquellos que volvian para «morir en España» en época del dictador; su carácter y su mentalidad de luchadora se lo impedian:

"Porque hay un gesto de dignidad, de entereza de carácter, una afirmación de incompatibilidad permanente, que nada mengua ni aminora, en el ejemplo que han dado y que dan los que prefieren morir en el Exilio, en el destierro - que significa "fuera de su tierra"- a ir a morir en España. Por grande que sea la nostalgia, la melancolia, la atracción de esa cuna que se abre de nuevo entre el musgo para acogernos, en toda alma bien templada, en todo espíritu fuerte, en toda persona no quebradiza, ha de haber el orgullo y la firmeza, la voluntad y la energía para no dar al enemigo el gusto feroz de recoger y enterrar nuestras cenizas. Porque, con ellas, son jirones de nuestra alma, de la lucha librada por el bien y por la justicia, contra el despotismo y el crimen, lo que se llevan" ${ }^{85}$.

82 lbid., p. 202.

83 Ibíd., p. 202

84 Ibid., p. 29.

85 Artículo de F. Montseny, extraído de: ALCALDE, C., Federica Montseny palabra en rojo y negro, Barcelona, Editorial Argos Vergara, 1983, p. 170. 


\section{FEDERICA MONTSENY EN SU MUERTE}

Federica Montseny fallece el 14 de enero de 1994 en Toulouse (Francia). La noticia será recogida, como no podía ser de otra forma, por los diferentes medios de comunicación. En el presente trabajo, vamos a utilizar dos periódicos de ámbito nacional: El País y El Mundo. En ellos, veremos como es tratada su persona en la sociedad del momento.

El País utilizará en su titular dos palabras que tienen cierta contradicción: “líder» y «libertaria»; pero que encajan perfectamente en lo que representa Federica Montseny para la memoria de nuestro país; así titulará: "Fallece la líder libertaria Federica Montseny". En el artículo, se hace un rápido repaso de su vida: se habla de sus padres; de su ingreso en la FAI y en CNT; de su pasado como escritora... pero la referencia principal, como en el período anterior, es el haber sido la primera mujer en España que formaba parte de un gobierno:

«Montseny ha pasado a la historia como la primera mujer que formó parte de un gobierno en España: de noviembre de 1936 a mayo de 1937 fue ministra de Sanidad y Asistencia Social en el Gobierno del socialista Largo Caballero..." ${ }^{86}$.

Como en la época de la Transición, se hace mención a su labor al frente de dicho ministerio:

«...se enfrentó a problemas que la guerra hizo acuciantes, como las cuestiones hospitalarias y la evacuación de refugiados. Cabe resaltar la creación de los liberatorios para prostitutas, donde se les ofrecía alojamiento y se les enseñaba un oficio, y la promulgación de una ley del aborto" ${ }^{87}$.

En parecidos términos, se expresa el diario El Mundo, que hace un breve repaso de su vida, poniendo especial interés en su figura como primera mujer que ocupaba un cargo ministerial. De su labor, al frente del mismo, destaca la legalización del aborto:

“...Federica Montseny, la primera mujer que ocupó una cartera ministerial en España e intentó introducir una legislación sobre la legalización del aborto (...) (su nombramiento como ministra) constituyó un acontecimiento por

El Pais, 16 de enero de 1994.

Ibíd.

El Mundo, 17 de enero de 1994.

Véase el artículo, «Federica Montseny y la CNT-FAl», Historia y Vida, n 90, Septiembre 1978. 
ser la primera vez que una mujer accedia a una cartera ministerial y por la aceptación de un cargo político por parte de uno de los líderes anarquistas, tradicionalmente opuestos a la participación en el aparato estatal» ${ }^{88}$.

Ninguno de los diarios hace mención de las dificultades a las que tuvo que hacer frente Federica Montseny al frente del Ministerio. Así como de los problemas para sacar adelante otros proyectos. Como relataba ella misma:

"...yo pretendía hacer una reforma dentro de mi sentido revolucionario y, a pesar de ello, encontré oposición permanente en todo el mundo (...) aludir a los boicoteados proyectos de reeducación de inválidos, Casas de Reposo para combatientes y Hogares infantiles, a la dísolución del "Comité Nacional de Refugiados" por ella creado en octubre, al abandono de la "Escuela de Puericultura" organizada en Valencia y del "Instituto de Higiene y de la Alimentación", a las "Casas de Solidaridad", a los "Libertarios de la Prostitución", a las "Casas del Ciego", a los centros de lucha antivenérea y contra el uso de estupefacientes...» 89 .

Al igual que sucede con las entrevistas publicadas en la época de la Transición, las referencias al exilio son muy escasas. Se sigue sin hacer mención a su papel en dicha época, y su importancia para el devenir del movimiento libertario:

“En 1945 se instaló en Toulouse, donde vivía desde entonces. En 1977 regresó por primera vez a España y luego hizo frecuentes visitas» ${ }^{90}$.

«Terminada la Guerra Civil se exilió en Francia, desde donde prosiguió su lucha contra Franco. Se instaló en Toulouse, donde vivió hasta que en el año 1977 regresó por primera vez a España" ${ }^{91 .}$

Diferentes políticos valorarán su figura, eso sí, buscando su parte más "positiva", es decir, se enfatizará en su papel de ministra, y en su lucha por los derechos de la mujer y de las clases más bajas. Al mismo tiempo, estos políticos, buscarán aquello que mejor coincide con sus planteamientos o necesidades de ese momento; aunque, en términos generales, poco tengan que ver con los ideales de la antigua militante cenetista. Son los casos de Angeles Amador y de Pilar Rahola.

La primera, en esos momentos Ministra de Sanidad, asistió al entierro de Federica en el cementerio de Saint Cyprien. Amador valorará el papel de Federica al frente del mismo Ministerio que ella ostenta en ese momento, y buscará hacer un paralelismo entre la labor de ambas:

91 El Mundo, 17 de enero de 1994. 
"Amador no regateó y supo ser generosa diciendo que Federica Montseny es un personaje de la historia de España "que ha defendido, con obstinación y coherencia, valores nobles del ser humano". "He pensado muchas veces - agregó la ministra en otro momento de su corta intervención-que hemos compartido la misma preocupación, porque a ella ya le preocuparon hace cincuenta años los problemas que tiene hoy la sociedad: el aborto, la prostitución y las condiciones de vida de los seres más desprotegidos" "92.

Pilar Rahola intentará «acoplar» la ideología de Federica y los valores anarquistas a sus planteamientos políticos. Así al hablar del legado libertario dice:

«..es la herencia que personalmente me gustaría reclamar, ¿Estado?, un Estado catalán, ciertamente, pero al menos Estado posible; ¿líderes?, sólo en la medida que sean permanentemente revisables; ¿verdades ideológicas?, ninguna preestablecida. $Y$ un humanismo comprometido que nos recuerde la dimensión humana en cada acción política” ${ }^{93}$.

En el mismo artículo, hará referencia a su papel como ministra y como defensora de los derechos de los más oprimidos:

"...Como tampoco muere su lucha por la justicia social, su defensa encendida de los derechos de las mujeres y de las clases más discriminadas, como no mueren sus decisiones como ministra, en tantos aspectos pioneros y clarividentes" ${ }^{94}$.

Los artículos que sobre ella, coincidiendo con su muerte, escriben diferentes columnistas, ahondan más en las contradicciones entre sus ideas y su vida. No faltarán los recuerdos sobre su paso por el Gobierno, las leyes que sacó adelante y la lucha por las mujeres. Pero, a diferencia con lo anterior, se hará mención, aunque de manera ligera, a sus enfrentamientos con otros compañeros libertarios.

\section{Eduardo Haro pondrá énfasis en su lucha interior:}

«El probable drama de esta militante estuvo en el desgarro entre la utopía y la realidad (...) El drama más considerable para Federica fue aceptar una cartera en el gobierno de la República (...) contra toda la ideología ácrata (...) hay quien cree que de ese momento viene la ruptura en lo movimientos (CNT,

92 El Mundo, 18 de enero de 1994.

93 Artículo de Rahola, P., "El legado moral de Federica Montseny", El Mundo, 25 de enero de 1994.

94 Ibid. 
FAl, sindicalistas) y que aún ahora, desde su silencio, su nombre está en el centro de las grandes polémicas (...) Probablemente la vida de esta mujer, representante de la pureza de la idea, ha sido su gran tragedia íntima» ${ }^{95}$.

Fermin Bocos destacará su fidelidad a las ideas anarquistas y su lucha:

"Veía las cosas desde la estatura de una edad y una experiencia herida por la amargura de la derrota y el exilio, pero seguía creyendo. No había perdido la fe en el ideal libertario (...) era la suya una preocupación por el día siguiente. Por la emancipación de los trabajadores y, sobre todo, por la causa particular de las mujeres" ${ }^{96}$.

Joan B. Culla hará hincapié en las paradojas de su vida:

«las paradojas constituyen un hilo conductor en la trayectoria de la vieja líder libertaria. Madrileña de nacimiento - pese a sus catalanísimos progenitores - (...) y su obra literaria y política se desarrolló fundamentalmente en castellano (...) jamás fue una trabajadora asalariada. Sus "condiciones objetivas" de vida fueron más bien las de una intelectual pequeño burguesa (...) Anarquista del ala dura, identificada con la FAl, vulneró, en noviembre de 1936, un principio sagrado de la acracia y aceptó ser ministra en el Gobierno de Largo Caballero. Las circunstancias lo justificaban y aquello para la anarquista fue un sacrificio, y para la feminista una victoria" ${ }^{97}$.

Más adelante, Culla hará mención al papel de Federica en la Transición y a sus fuertes polémicas con otros militantes anarquistas:

«Montseny contribuyó en los primeros años de la transición a reconstruir en el imaginario colectivo un período - la República y la guerra civil-que el franquismo quiso borrar o falsear. Polemista temible, fue objeto de grandes polémicas y recibió en su piel las erosiones de un exilio libertario inagotable de querellas, enfrentamientos y escisiones" ${ }^{98}$.

\section{CONCLUSIONES}

De las tres etapas que se han analizado en el trabajo: exilio, Transición y muerte, se aprecia una diferencia clara entre la primera y las dos últimas.

En la primera, el análisis proviene de la Memoria Colectiva, es decir, la del grupo libertario, y está marcada por una fuerte polémica sobre la figura

\footnotetext{
95 Articulo de HARO, E., "La tragedia de una luchadora pura", El País, 16 de enero de 1994. Artículo de Bocos, F., "Federica", El Mundo, 17 de enero de 1994.

Artículo de CulLA, J.B.,: “Paradojas de una figura», El País, 16 de enero de 1994.

98 Ibíd.
} 
de Federica Montseny. Se le hará, en muchos aspectos, responsable de las situaciones de enfrentamiento y de la escisión que sufre el movimiento anarquista en el exilio.

En la época de la transición, en general, se quiere recuperar una parte de la Memoria Histórica que había sido sustraída por el régimen franquista; que había impuesto un Olvido Oficial; por un lado, sobre los períodos de la República y de la Guerra Civil, y por otro, sobre personajes emblemáticos de los perdedores de la Guerra.

Una parte de la recuperación de esta Memoria Histórica vendrá de la mano de libros y publicaciones periódicas. Pero, otra parte importante tendrá como referente fundamental la Memoria Individual de personas que, como Federica Montseny, darán una visión de la historia diferente a la oficial, que hasta esos momentos había dominado.

Paralelamente a esta nueva visión de la historia pasada, tendrá lugar la rehabilitación de muchos de estos personajes, como es el caso de Federica Montseny. De ella, se valorará especialmente su labor al frente del Ministerio de Salud; la legislación sobre el aborto; el haber sido la primera mujer que ocupaba dicho cargo en la historia de España; así como su preocupación por los más desprotegidos. Todo ello, en consonancia con los nuevos planteamientos de la sociedad democrática.

El Olvido, en este período, viene determinado por aquello que, con la idea que se pretende transmitir, le resulta ajeno. A este respecto, se obvian circunstancias más comprometidas, como es el caso del exilio.

En el momento de su muerte se sigue, en general, con la misma visión del personaje que en la Transición. Valorando su paso por el gobierno republicano, su labor al frente del mismo... aunque se da mayor importancia a su dimensión «feminista», en cuanto preocupada por los problemas de la mujer. Al mismo tiempo, se hace mención a las contradicciones en su vida y a la situación en el exilio.

Estos planteamientos tienen que ver, al igual que en la transición, con la situación que se vive en la sociedad en ese momento; donde ha declinado la importancia de organizaciones políticas y sindicales, y surgen otros movimientos: ecologistas, feministas, homosexuales, etc.

En definitiva, la figura de Federica Montseny ha tenido dos visiones completamente opuestas: por un lado, la de un grupo de sus compañeros anarquistas que han visto en su persona uno de los grandes problemas con los que se ha tenido que entrentar el movimiento libertario, tanto en los tiempos de la República como en la Guerra Civil y principalmente en el exilio; por otro lado, la visión que se aporta desde la 
muerte de Franco, valorándose, de la vida de Federica, aquello que, en cada momento, le era más cercano a la nueva sociedad que se estaba construyendo en España.

\section{BIBLIOGRAFÍA}

AlCAlde, C., Federica Montseny palabra en rojo y negro, Barcelona, Editorial Argos Vergara, 1983.

Álvarez, R., Historia negra de una crisis libertaria, México, Editores Mexicanos Unidos, 1982.

Borrás, J., Políticas de los exiliados españoles 1944-1950, Chatillon-sous-Bagneux, Ruedo lbérico, 1976.

BorRÁs, J., Del Radical-Socialismo al Socialismo Radical y Libertario, Madrid, Fundación Salvador Seguí, 1998.

LORENZO, C.M., Los anarquistas españoles y el poder, París, Ruedo lbérico, 1972.

Marco Nadal, E., Todos contra Franco. La ANFD 1944-1947, Madrid, Queimada Ediciones, 1982.

Martin Morales, E., Federica Montseny, Barcelona, Labor, 1992.

MAteos, A., Las izquierdas españolas desde la Guerra Civil hasta 1982, Madrid, UNED, 1997. Miro, F., Anarquismo y Anarquistas, Editores Mexicano Unidos, S.A., 1979.

Miro, F., ¿Y España Cuándo?, México, Editorial B. Costa Amic, 1959.

Montseny, F., Mis primeros cuarenta años, Barcelona, Plaza y Janes, 1987.

MONTSENY, F., Seis años de mi vida 1939-1945, Barcelona, Galba, 1978.

PAZ, A., CNT 1939/1951, Barcelona, Hacer, 1982.

VV.AA, La oposición libertaria al régimen de Franco, 1936-1975, Madrid, Fundación Salvador Seguí, 1993.

\section{REVISTAS}

Destino

Historia y vida

Tiempo de Historia

Sábado Gräfico

DIARIOS

El Mundo

El País 